ISSN 1392-3196 / e-ISSN 2335-8947

Zemdirbyste-Agriculture, vol. 105, No. 4 (2018), p. 357-362

DOI $10.13080 / \mathrm{z}-\mathrm{a} .2018 .105 .045$

\title{
Virus-induced gene silencing for functional analysis of eds1 gene in tomato infected with Ralstonia solanacearum
}

\author{
Hamid Reza BOLOK YAZDI ${ }^{1}$, Seyed Kazem SABBAGH ${ }^{2}$, Mahta MAZAHERI ${ }^{3}$, \\ Mohammad SALARI ${ }^{1}$, Seyed Mohammad MOSHTAGHIOUN ${ }^{2}$ \\ ${ }^{1}$ University of Zabol \\ Zabol, Iran \\ ${ }^{2}$ Campus of Science, Yazd University \\ Yazd, Iran \\ E-mail: sksabbagh@yazd.ac.ir \\ ${ }^{3}$ Shahid Sadoughi University of Medical Sciences \\ Yazd, Iran
}

\begin{abstract}
The efficiency of virus-induced gene silencing (VIGS) can be identified by monitoring the level of silencing of the target genes in plants. In this study, enhanced disease susceptibility 1 (eds 1 ) gene was silenced in tomato (Lycopersicon esculentum L.) plants by VIGS, using Tobacco rattle virus (TRV) expression vector. Tomato plants at different growth stages (fully-opened cotyledon and eight-leaf) were co-infected with Agrobacterium tumefaciens $\mathrm{C} 58 \mathrm{C} 1$ strain containing eds 1 complementary deoxyribonucleic acid (cDNA) at different $\left(20^{\circ} \mathrm{C}\right.$ and $28^{\circ} \mathrm{C}$ ) temperatures and bacterial concentrations with $1.0 \times 10^{6}$ and $1.5 \times 10^{8}$ colony forming unit $(\mathrm{CFU}) \mathrm{mL}^{-1}$. The reverse transcriptase-polymerase chain reaction (RT-PCR) method was used to analyse the suppression level of the eds 1 gene and the VIGS efficiency assay. Data analysis showed a high eds 1 gene silencing at fully-opened cotyledon stage at $20^{\circ} \mathrm{C}$ using a $A$. tumefaciens at a concentration of $1.0 \times 10^{6} \mathrm{CFU}$ rather than other conditions. In addition, the percentage of wilted plants was significantly varied in different conditions and the most wilted plants were observed at the $1.0 \times 10^{6} \mathrm{CFU}$ and $20^{\circ} \mathrm{C}$.

Based on our results, we suggest that eds 1 gene silencing can be used as a possible screening marker to select bacterial wilt-resistant species.
\end{abstract}

Key words: Agrobacterium tumefaciens, agro-infiltration, eds1, Ralstonia solanacearum, virus-induced gene silencing.

\section{Introduction}

Virus-induced gene silencing (VIGS) is known as an effective RNA-mediated gene silencing mechanism to suppress the transcriptional and post-transcriptional expression of targeted genes in plants (Holoch, Moazed, 2015). The VIGS occurs when a homologous RNA similar to host gene is introduced to a host cell by a virus plasmid and leads to degradation of the target mRNA (Unver, Budak, 2009; Vaistij, Jones, 2009). Recently, many recombinant vectors have been derived from viral genomes and have been adapted for a wide range of plant species. A novel construct of Tobacco rattle virus (TRV) vector is one of the most efficient VIGS vectors and has been widely used in various plants, such as Arabidopsis thaliana (Bond, Baulcombe, 2015), Nicotiana benthamiana (Senthil-Kumar, Mysore, 2011) and Lycopersicon esculentum (Kandoth et al., 2007). Optimization of Tobacco rattle virus (TRV)-induced gene silencing has showed that some parameters, including concentration and pre-incubation of Agrobacterium, the ecotypes, the growth stages and temperature of agro-

inoculated plants, have potentially affected the VIGS efficiency (Wang et al., 2006; Bhaskar et al., 2009). The optimal temperature for plant growth is very variable in different plant species (Abrami, 1972; Hatfield, Prueger, 2015). Tomato plants show drastically reduced VIGS efficiency at temperatures above $21^{\circ} \mathrm{C}$ (Patil, Fauquet, 2015). Additionally, the growth temperature of agroinoculated plants was identified as a factor which can cause a faster viral amplification, more formation of short-interfering RNAs and plant growth (Szittya et al., 2003; Ali et al., 2013).

Ralstonia solanacearum is known as the second important plant bacterial pathogen in the world after Pseudomonas syringae pathovars (Mansfield et al., 2012) and has been considered as a model in the plant pathology, biotechnology and genetic engineering studies (Hu et al., 2008; Wicker et al., 2012). In signalling pathway of plant disease, resistance is often mediated by corresponding gene pairs in the plant (resistance or $R$ gene) and pathogen (a virulence or Avr gene). Gene eds 1 primarily mediates

Please use the following format when citing the article:

Bolok Yazdi H. R., Sabbagh S. K., Mazaheri M., Salari M., Moshtaghioun S. M. 2018. Virus-induced gene silencing for functional analysis of eds1 gene in tomato infected with Ralstonia solanacearum. Zemdirbyste-Agriculture, 105 (4): $357-362$. DOI $10.13080 / \mathrm{z}-\mathrm{a} .2018 .105 .045$ 
signalling derived from the TIR-NB-LRR class of $R$ proteins and is indispensable for the function of these $R$ genes (Narusaka et al., 2013). The activated eds 1 gene is located in the up-stream of salicylic signalling pathway (Ding et al., 2015). So eds 1 gene over-expression could increase salicylic acid accumulation in infected plant tissues in response to pathogen attacks. In tomato, eds 1 gene has a key role in mediating resistance to a broad range of pathogens (viral, bacterial and fungal pathogens), yet shows imperative specificity for the function of $R$ genes and is required in the receptor-like $R$ gene class (Ercolano et al., 2012; Schön et al., 2013).

The aim of this study was to determine Tobacco rattle virus virus-induced gene silencing (TRV-VIGS) efficiency system through morphological and molecular indicators by measuring the suppression of the eds 1 gene expression and percentage of wilted tomato plants under different conditions, including growth development, temperature and bacterial concentration, to obtain the best conditions for reaching the highest VIGS efficiency.

\section{Materials and methods}

Plant materials and growth conditions. Tomato (Lycopersicon esculentum L., cultivar 'Khorram') seeds were provided by the Agricultural Research
Institute, Yazd, Iran and were grown in green-house conditions during the summer 2016. The seeds were surface-sterilized in $1.5 \%$ sodium hypochlorite for 5 min, washed three times with sterile distilled water, and then were cultured in pots containing vermiculite perlite $(1: 1)$ mixture. The plants were regularly irrigated in greenhouse conditions at $20^{\circ} \mathrm{C}$ and $28^{\circ} \mathrm{C}$ under 16 -hour light, 8-hour dark cycles with relative humidity of $75 \%$. Tomato plants at the fully-opened cotyledon and eightleaf stages were used for agro-infection assay.

Construction of Tobacco rattle virus (TRV)derived vectors. The Gateway entry clones ( $\mathrm{pENTR} 11)$ containing pUC ori and attL1 and attL2 regions were used in this work. Enhanced disease susceptibility 1 (eds 1$)$ as target gene, beta-glucuronidase (gus) and phytoene desaturase ( $p d s)$ genes as negative and positive controls respectively, were PCR-amplified using specific primers (Table 1) using tomato complementary deoxyribonucleic acid (cDNA) sources from infected tomato by Ralstonia solanacearum.

Inftection of tomato plants by Ralstonia solanacearum. In this study, $20 \mathrm{~mL}$ of a $R$. solanacearum suspension with the optical density (OD) at a wavelength of $600 \mathrm{~nm}\left(\mathrm{OD}_{600}\right)$ of 1.0 was freshly prepared and poured over the surface of soil at 2-4 tomato leaf stage of growth. The scores of the disease symptoms in the

Table 1. The characteristics of the primers used in this study

\begin{tabular}{ccc}
\hline Gene & Forward sequence (5'-3') & $\begin{array}{c}\text { Fragment length } \\
\text { bp }\end{array}$ \\
\hline$e d s l-\mathrm{F}$ & GAGGCTGTTGCACGATC & 450 \\
$e d s l-\mathrm{R}$ & GCTCTTGTACTCAGGCCAA & 283 \\
pTRV2-F & CGTTGAGAATCCAGATGCTGT & \\
pTRV2-R & ACGAAGACACAACCTTGCTC & 414 \\
$g u s-\mathrm{F}$ & CGCCATTTGAAGCCGATGTCAC \\
$g u s-\mathrm{R}$ & AGAGATAACCTTCACCCGGTTGC & 409 \\
$p d s-\mathrm{F}$ & CGGTCTAGAGGCACTCAACTTTATAA & 4 \\
$p d s-\mathrm{R}$ & CGGGGATCCCTTCAGTTTCTGTC & \\
\hline
\end{tabular}

plants were recorded six times from the sixth day after the infection to the end of the experiment.

Total RNA extraction and reverse transcriptasepolymerase chain reaction (RT-PCR) analysis. Total RNA extraction was carried out using a RNX-Plus solution (SinaClon, Iran) according to the manufacturer's protocol. First strand cDNA synthesis was made by using $500 \mathrm{ng}$ of total RNA, random hexamer primers and reverse transcriptase enzyme (SinaClon, Iran). Then, cDNA was recombined into pENTR11 by BP (BP Clonase ${ }^{\mathrm{TM}}$ II enzyme) recombination reaction. Thereafter, LR (Gateway ${ }^{\circledR}$ LR Clonase ${ }^{\mathrm{TM}}$ ) recombination reaction was applied to transfer the inserts from pENTR11 clones into pTRV-RNA2-Gateway. pENTR11 carrying the cDNA of eds 1 gene (50 to $150 \mathrm{ng}$ ) was flanked between attL1 and attL2 regions and mixed with the destination vector (pTRV-RNA2-Gateway) $150 \mathrm{ng} \mu \mathrm{l}^{-1}$ (Fig. 1). Briefly, pENTR11 was mixed with $150 \mathrm{ng} \mu^{-1}$ of the destination vector DNA (pTRV-RNA2-Gateway) and $2 \mu \mathrm{l}$ of LR Clonase II enzyme, then filled up to $10 \mu \mathrm{l}$ of TE buffer (Tris-EDTA, $\mathrm{pH} 8.0$ ). The mixture was then kept in a sealed glass vial at room temperature for 1 hour. Enzymes were inactivated with $1 \mu \mathrm{l}$ of the proteinase $\mathrm{K}$ solution $\left(2 \mu \mathrm{g} \mu \mathrm{l}^{-1}\right)$ for $10 \mathrm{~min}$ at $37^{\circ} \mathrm{C}$. The presence of insert was checked by PCR method using specific primers related to each gene.

Virus-induced gene silencing (VIGS). These experiments were performed by using the Agrobacterium tumefaciens strain C58C1 containing pTRV1 and pTRV2. Bacterial strains were separately grown in an LB medium

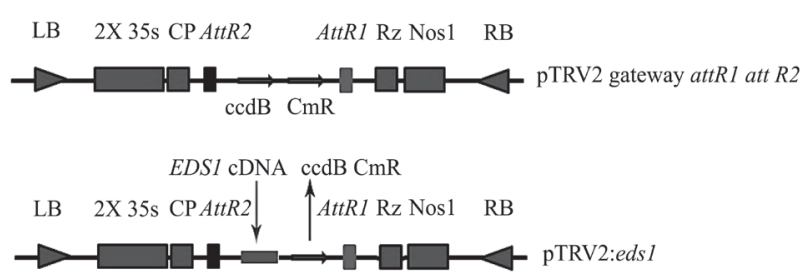

Figure 1. Schematic figure of Gateway LR reaction and recombinant of eds 1 gene into pTRV2

containing $10 \mathrm{mM}$ MES and $20 \mathrm{mM}$ acetosyringone with appropriate antibiotics. After one day, bacterial cells were harvested and re-suspended in infiltration buffer $(10 \mathrm{mM}$ $\mathrm{MgCl}_{2} 10 \mathrm{mM}$ MES, pH 5.6 and $150 \mathrm{mM}$ acetosyringone) to obtain a final OD of 1.0 and 2.0 in both pTRV 1 and pTRV2. Tomato plants infiltration was done in fullyopened cotyledon and eight-leaf stages at $20^{\circ} \mathrm{C}$ and $28^{\circ} \mathrm{C}$ with a $1 \mathrm{~mL}$ needleless syringe. The plants inoculated with pTRV2 alone were used as a control.

Percentage of the wilted plants. The percentage of the wilted plants was calculated by the following formula: PWP $=\Sigma$ (percent of wilted plants) / total plants.

Statistical analysis. The data in this study were analysed using the analysis of variance ( $A N O V A)$ protocol to determine any significant difference among the treatments. The software SPSS, version 22.0 was used for the statistical analyses. The statistical significance level was considered to be $\alpha=0.05$. This study was carried out in three replications each containing 15 plants. 


\section{Results}

Detection of pTRV2 constructs. pTRV2 detection was done using specific primers based on a conserved sequence of the partial coat protein of Tobacco rattle virus. The expected size of pTRV (283 bp length) was detected in all agro-inoculated plants at different conditions.

The expression level of pTRV2 was significantly increased in the fully-opened cotyledon stage when compared to eight-leaf stage in infected tomato plants with Agrobacterium at $20^{\circ} \mathrm{C}$ (Fig. 2). So based on these results, we suggest that the replication of pTRV2 could be affected by different stages of plant growth and temperature. The most replication of pTRV2 was observed in the fully-opened cotyledon stage at $20^{\circ} \mathrm{C}$.

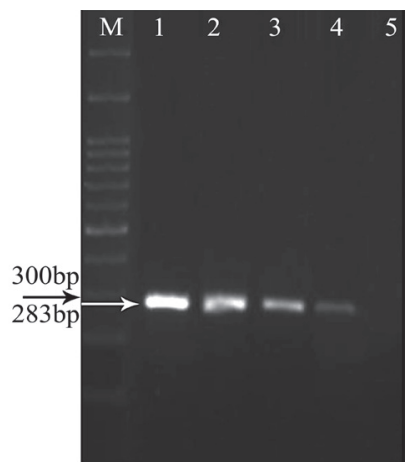

$\mathrm{M}$ - ladder ( $1 \mathrm{k} \mathrm{bp})$; line 1 - fully-open cotyledon stage at $20^{\circ} \mathrm{C}$ line 2 - eight-leaf stage at $20^{\circ} \mathrm{C}$, line 3 - fully-opened cotyledon stage at $28^{\circ} \mathrm{C}$, line 4 - eight-leaf stage at $28^{\circ} \mathrm{C}$, line 5 - non agro-inoculated plants (negative control)

Figure 2. The amplification of pTRV2 using RT-PCR analysis in tomato plants infected via ago-infection method

Tomato wilting and suppression of the eds1 gene. Tomato plants were infected with Agrobacterium tumefaciens at a concentration of $1.0 \times 10^{6} \mathrm{CFU}$. Two growth stages (i.e. fully-opened cotyledon and eightleaf stages) and two temperatures $\left(20^{\circ} \mathrm{C}\right.$ and $\left.28^{\circ} \mathrm{C}\right)$ were used to analyse agrobacterium-mediated virus infection. The results indicate that different growth stages and temperature conditions can change the efficiency of gene silencing in tested groups. The eds 1 gene expression was completely silenced in fully-opened cotyledon stage in approximately all agro-infected plants at $20^{\circ} \mathrm{C}$. High percentage of wilting in infected tomato plants by $R$. solanacearum confirms eds 1 gene suppression (Fig. 3).

Percentage of wilted plants in the eds1 genesilenced plants. The highest percentage of wilting was observed in the fully-open cotyledon stage at $20^{\circ} \mathrm{C}$ temperature compared to eight-leaf stage at the same temperature. At $28^{\circ} \mathrm{C}$, the wilting symptoms were significantly reduced when compared to $20^{\circ} \mathrm{C}$ at both growths stages (Table 2). At this temperature slight wilting was observed. These results indicate that low temperature could influence the efficiency of gene silencing at different growth stages.

The progress of disease was surveyed 6-21 days post infection (DPI) in silenced tomato plants infected with $R$. solanacearum. Our data showed that the high wilting percentage occurred at fully-opened cotyledon stage at $20^{\circ} \mathrm{C}$ at $16-21$ days post infection with $R$. solanacearum. At $6^{\text {th }}$ day post infection, plant wilting percentage was reduced but this reduction was not significant between different growth conditions (Fig. 4). The pTRV2 empty plasmid was used as control for monitoring disease progression.

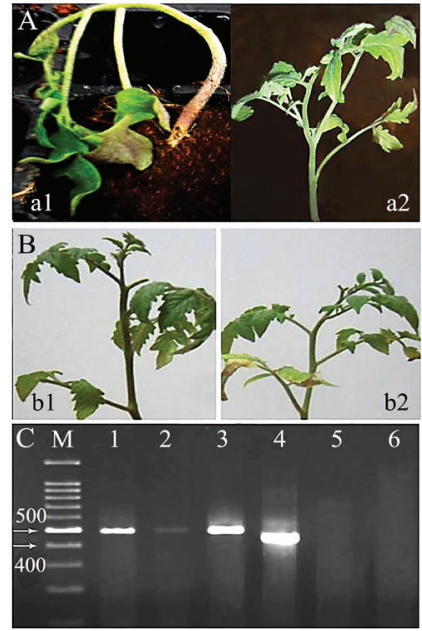

Note. The effect of growth stage and temperature on gene silencing in tomato plants infected by Agrobacterium tumefaciens: (A) agro-infected tomato plants: a1 - in fullyopened cotyledon stage at $20^{\circ} \mathrm{C}$, a2 - eight-leaf stage at $20^{\circ} \mathrm{C}$; (B) agro-infected tomato plants: b1 - in fully-opened cotyledon stage, b2 - eight-leaf stage at $28^{\circ} \mathrm{C}$; (C) efficiency of VIGS based on suppression of the eds 1 gene: $\mathrm{M}$ - ladder (1k bp), line 1 - eight-leaf stage at $20^{\circ} \mathrm{C}$ (semi-efficiency), line 2 - fullyopened cotyledon stage at $28^{\circ} \mathrm{C}$ (high efficiency), line 3 - eightleaf stage at $28^{\circ} \mathrm{C}$ (low efficiency), line $4-$ gus gene (negative control), line 5 - fully-opened cotyledon stage at $20^{\circ} \mathrm{C}$ (highest efficiency), line $6-p d s$ gene (positive control).

Figure 3. Presence of wilting symptoms and level of eds1 gene silencing

Table 2. Wilting percentage at different plant growth stages and temperature conditions in the infected tomato

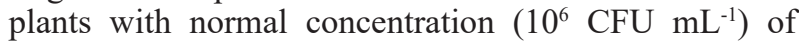
Agrobacterium tumefaciens $\mathrm{C} 58 \mathrm{C} 1$ strain

\begin{tabular}{lcc}
\hline \multirow{2}{*}{ Plant growth stage } & \multicolumn{2}{c}{ Wilting (\%) in two temperatures } \\
\cline { 2 - 3 } & $\mathrm{C}^{\circ} 20$ & $\mathrm{C}^{\circ} 28$ \\
\hline Fully-opened cotyledon & $85.4 \pm 1.1 \mathrm{a}$ & $79.9 \pm 0.9 \mathrm{~b}$ \\
Eight-leaf & $76.7 \pm 1.6 \mathrm{c}$ & $66.4 \pm 1.6 \mathrm{~d}$ \\
\hline
\end{tabular}

Note. The different letters show what means are significantly different according to the LSD at $p<0.05$; mean + SD.

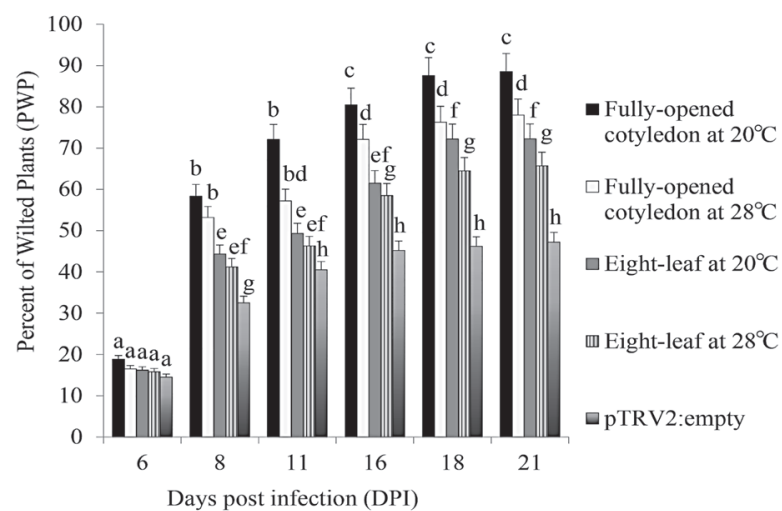

Note. The susceptibility of eds 1 gene-silenced plants infected with $R$. solanacearum from $6^{\text {th }}$ to $21^{\text {st }}$ day post infection at different growth stage and temperature; more-severe wilting symptom caused by $R$. solanacearum in fully-opened cotyledon stage at $20^{\circ} \mathrm{C}$ compared to other conditions; each value is the mean of three biological replicates; letters show data that are of equal variance but significantly different $(p<0.05$; all data are mean \pm standard error)

Figure 4. Effect of $e d s 1$ gene silencing on the percentage of wilting symptoms in tomato plants infected with Ralstonia solanacearum at eighth-leaf stage 
Bacterial concentration and efficiency of virus-induced gene silencing (VIGS). The effect of bacterial concentration on gene silencing efficiency was investigated in silenced plants against eds 1 gene by agro-infection assay. Based on results of wilting assay, we used just infected tomato plants in the fully-opened cotyledon stage. For this experiment, two concentrations

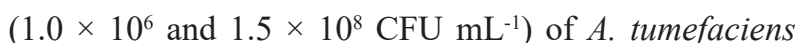
were used. All experiments were done at $20^{\circ} \mathrm{C}$. The results of plant infection and wilting assay showed that plant wilting percentage is significantly decreased at high concentration of A. tumefaciens in eds 1 gene-silenced plants when compared to normal concentration (Table 3).

Table 3. Percentage of wilted tomato plants at fully-opened cotyledon stage at $20^{\circ} \mathrm{C}$ infected by different concentrations of Agrobacterium tumefaciens C58C1 strain

\begin{tabular}{|c|c|c|c|c|}
\hline \multirow{2}{*}{ Plant growth stage } & \multirow{2}{*}{ Temperature } & \multicolumn{2}{|c|}{ Wilting (\%) at two concentrations } & \multirow{2}{*}{$P$ value } \\
\hline & & $1.0 \times 10^{6} \mathrm{CFU} \mathrm{mL}^{-1}$ & $1.5 \times 10^{8} \mathrm{CFU} \mathrm{mL}^{-1}$ & \\
\hline Fully-opened cotyledon & $20^{\circ} \mathrm{C}$ & $85.4 \pm 1.1 \mathrm{a}$ & $79.9 \pm 0.9 \mathrm{~b}$ & 0.004 \\
\hline
\end{tabular}

Note. The values following different letters in a column are significantly different from each other at $p \leq 0.05$; each value is the mean of three replications, including 15 plants per repetition; mean $+\mathrm{SD}$.

RT-PCR method was used to measure the silencing level of $e d s 1$ gene in agro-infected tomato plants with two different concentrations of $A$. tumefaciens. The result of RT-PCR analysis showed no-amplified fragment related to eds 1 gene in infected plants with $A$. tumefaciens

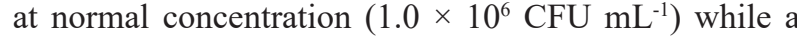
clear band related to eds 1 gene was observed in infected tomato plants with high bacterial concentration $\left(1.5 \times 10^{8}\right.$ CFU mL m $^{-1}$ ) (Fig. 5).

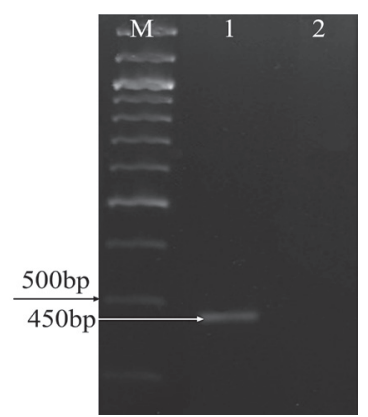

$\mathrm{M}$ - ladder (1k bp); silencing level in infected plants with: line 1 - bacterial concentration at $1.5 \times 10^{8} \mathrm{CFU} \mathrm{mL}^{-1}$, line 2 bacterial concentration at $1.0 \times 10^{6} \mathrm{CFU} \mathrm{mL}^{-1}$

Figure 5. Bacterial concentration and silencing level of eds1 gene

These results indicate a positive correlation between bacterial concentration and gene silencing. Thus, we confirmed that silencing of eds 1 gene is noticeably affected by the low bacterial concentration.

\section{Discussion}

Tomato wilting disease, caused by $R$. solanacearum, is one of the most destructive diseases of tomato which lead to crop loss in greenhouse cultures in Iran. Use of resistant plants for disease control is the main objective of many studies in the vegetables science research laboratory. Virus-induced gene silencing (VIGS) has been set up successfully to understand the functional analysis of different pathogenesis-related genes involved in plant disease resistance against pathogenic agents (Ramegowda et al., 2014; Lee et al., 2015). In this work, we attempted to investigate the key role of eds 1 gene in resistance of tomato to bacterial wilting disease caused with $R$. solanacearum by using VIGS approach. Firstly, we detected pTRV2 by specific primers and the PCR-amplifying showed the expected 283-bp-fragment of eds 1 gene. These observations indicated that pTRV2 could be noticeably replicated in infected tomato plants. Relative transcript fragments were differentially detected in infected tomato plants. Secondly, silencing efficiency of eds l gene was assayed in different conditions. Growth conditions such as developmental stage and photoperiodic conditions are the most important factors for determination of VIGS efficiency. The efficiency of virus-induced gene silencing with Soybean yellow common mosaic virus (SYCMV) in soybeans has been investigated by using quantitative reverse transcriptasepolymerase chain reaction (qRT-PCR) method at different plant growth stages. These results showed a high VIGS efficiency at the primary leaves stage and low efficiency at closed cotyledon stage (Kim et al., 2016). We found that silencing of $e d s 1$ gene was more effective in the inoculated seedlings at fully-opened cotyledon stage, whereas at the eight-leaf stage, VIGS efficiency was significantly reduced.

The effect of temperature on enhancement of VIGS in infected tomato plants has showed that the VIGS efficiency was affected by low temperature and low humidity $(30 \%)$ and at high temperature $\left(21^{\circ} \mathrm{C}\right)$, VIGS efficiency was significantly reduced ( $\mathrm{Fu}$ et al., 2006). The host and environmental factors have an important role in viral RNA recombination that could lead to increase of VIGS efficiency (Jaag, Nagy, 2010). The role of temperature in VIGS efficiency has been studied on different plants using agroinfection method and has suggested that temperature can influence silencing efficiency by affecting vector DNA accumulation and the spread of endogenous gene silencing in tomato (Fu et al., 2006; Cai et al., 2007), cotton (Tuttle et al., 2008) and Nicotiana benthamiana (tobacco) and Solanum lycopersicon (tomato) as well as Arabidopsis (Padmanabhan, Savithramma, 2009). Also the role of environmental factors, including temperature, light intensity, humidity and plant growth stages, has been strictly demonstrated on VIGS efficiency (Liscombe, O'Connor, 2011; Kim et al., 2016). The optimal temperature to achieve a high VIGS efficiency has been typically determined in soybean cyst nematode $\left(27^{\circ} \mathrm{C}\right)$, bacterial leaf pustule $\left(28^{\circ} \mathrm{C}\right)$ and rust bioassays $\left(25-30^{\circ} \mathrm{C}\right)$ (Zhang et al., 2010). Our observation showed that the optimal temperature is $20^{\circ} \mathrm{C}$ with a high VIGS efficiency and this temperature did not show any tomato growth limitation. In SYCMV-based VIGS system this parameter has been determined at $27^{\circ} \mathrm{C}$ (Kim et al., 2016). The high-efficiency VIGS at the low temperature is due to the high susceptibility of plants to viruses because at the high temperature, siRNAs is slowly accumulated and then RNA silencing will be displayed to lower level (Tuttle et al., 2008; Sung et al., 2014). However, we suggest use of low temperature and normal bacterial concentration to achieve a high VIGS efficiency.

A down expression and complete silencing of eds 1 gene was determined at 9 days post infection using semi-quantitative PCR analysis. Down regulation of 
pds gene in California poppy (Eschscholzia californica Cham.) has been shown by VIGS technique. Two week after agro-infiltration, $92 \%$ of the manipulated plants showed intense reduction of $p d s$ gene expression level (Wege et al., 2007). In this study, we also showed strong eds1 gene silencing at 16-21days post infection with $R$. solanacearum

Replication of viral genome is critical to reach a high silencing efficiency. It has been shown that silencing in $N$. benthamiana plant by using Agrobacterium tumefaciens harbouring pTRV1, pTRV2 and pTRV2$p d s$ is more efficient than tomato plant. Also, choice of suitable strains of $A$. tumefaciens is pivotal to increase VIGS efficiency. Usually, in tomato, the A. tumefaciens GV3101 strain is used while in two $N$. benthamiana GV3101 and GV2260 strains are used (Liu et al., 2002) but in this study, we used the A. tumefaciens $\mathrm{C} 58 \mathrm{C} 1$ strain for agro-infection and a high silencing efficiency was observed. The difference of bacterial strains for agro-infection is related to resistance to antibiotics and use of suitable strains is dependent on the protocol of each laboratory and their experience.

Silencing efficiency of SpPDS and SpMPK1 genes in Solanum pimpinellifolium has been evaluated with two bacterial concentration $\left(\mathrm{OD}_{600}=1.0\right.$ and 2.0). Evaluation method included four indexes as: (1) silencing frequency of plants, (2) silencing efficiency of a plant, (3) silencing frequency of each leaf and (4) silencing efficiency of each gene. A high silencing efficiency of both targeted genes was determined at OD $_{600}$ of 2.0 (Wang et al., 2006).

In this study, we calculated some of these indexes such as silencing efficiency in leaf and total plant and also gene expression level in the infected tomato plants with two bacterial concentrations.

Our results showed that a normal bacterial concentration $\left(1.0 \times 10^{6} \mathrm{CFU} \mathrm{mL}^{-1}\right)$ could increase wilting symptoms that indicate a high silencing efficiency of $e d s 1$ gene, whereas at the high concentration of $A$. tumefaciens $\left(\mathrm{OD}_{600}=2.0\right)$ silencing efficiency was significantly reduced when compared to normal concentration $\left(\mathrm{OD}_{600}=1.0\right)$. Our data showed that bacterial concentration of $1.0 \times$ $10^{6} \mathrm{CFU} \mathrm{mL} \mathrm{mL}^{-1}$ will be more efficient for VIGS in tomato plants infected with $R$. solanacearum. These data are not in line with the results of $\mathrm{Li}$ et al. (2006), which show that bacterial concentration with $\mathrm{OD}_{600}=2.0$ led to high VIGS efficiency. This contradiction can result from two parameters: first, their high temperature $\left(24^{\circ} \mathrm{C}\right)$ compared to our temperature conditions at $20^{\circ} \mathrm{C}$, and second, the presence of $R$. solanacearum in our infected tomato plants.

\section{Conclusion}

In this work, we showed that the efficiency of virus-induced gene silencing (VIGS) approach can be affected by bacterial concentration and plant growth conditions. Infecting of tomato seedlings by Tobacco rattle virus (TRV) vector can induce gene silencing in the youngest leaf at the open cotyledon stage. Based on these results, we could conclude that eds 1 gene has a pivotal role to confer resistance to tomato plants. High wilting intensity in eds 1 gene-silenced tomato plants using VIGS approach confirmed our claim. Therefore, VIGS could be used as a powerful tool to achieve a constant transformation in different varieties of tomato. It seem that despite growth conditions and temperature, change of $\mathrm{pH}$, nutrient, irrigation and salinity will help us to increase the efficiency of this technique.

\section{Acknowledgements}

We thank Dr. Bushra Mirza and Dr. Matthieu Joosten (Quaid-i-Azam University, Pakistan and Wageningen University, The Netherlands, respectively) for kindly providing Agrobacterium tumefaciens strain and pTRV1 vector.

Received 02122017

Accepted 03072018

\section{References}

1. Abrami G. 1972. Optimum mean temperature for a plant growth calculated by a new method of summation. Ecology, 53 (5): 893-900. https://doi.org/10.2307/1934305

2. Ali E. M., Kobayashi K. Yamaoka N., Ishikawa M., Nishiguchi M. 2013. Graft transmission of RNA silencing to non-transgenic scions for conferring virus resistance in tobacco. PLoS One, 8 (5): e63257.

https://doi.org/10.1371/journal.pone.0063257

3. Bhaskar P. B., Venkateshwaran M., Wu L., Ané J. M., Jiang J. 2009. Agrobacterium-mediated transient gene expression and silencing: a rapid tool for functional gene assay in potato. PLoS One, 4 (6): e5812.

https://doi.org/10.1371/journal.pone.0005812

4. Bond D. M., Baulcombe D. C. 2015. Epigenetic transitions leading to heritable, RNA-mediated de novo silencing in Arabidopsis thaliana. Proceedings of the National Academy of Sciences, 112: 917-922. https://doi.org/10.1073/pnas.1413053112

5. Cai X., Changchun W. Y., Xu Q. X., Zhong Z., Xueping Z. 2007. Efficient gene silencing induction in tomato by a viral satellite DNA vector. Virus Research, 2: 169-175. https://doi.org/10.1016/j.virusres.2006.12.016

6. Ding Y., Shaholli D., Mou Z. 2015. A large-scale genetic screen for mutants with altered salicylic acid accumulation in Arabidopsis. Frontiers in Plant Science, 5: 763. https://doi.org/10.3389/fpls.2014.00763

7. Ercolano M. R., Sanseverino W., Carli P., Ferriello F., Frusciante L. 2012. Genetic and genomic approaches for $\mathrm{R}$-gene mediated disease resistance in tomato: retrospects and prospects. Plant Cell Reports, 31 (6): 973-985. https://doi.org/10.1007/s00299-012-1234-Z

8. Fu D. Q., Zhu B.Z., Zhu H. L., Zhang H.X. 2006. Enhancement of virus-induced gene silencing in tomato by low temperature and low humidity. Molecules and Cells, 21: 153-160.

9. Hatfield J. L., Prueger J. H. 2015. Temperature extremes: effect on plant growth and development. Weather and Climate Extremes, 10: 4-10.

https://doi.org/10.1016/j.wace.2015.08.001

10. Holoch D., Moazed D. 2015. RNA-mediated epigenetic regulation of gene expression. Nature Reviews. Genetics, 16 (2): 71-84. https://doi.org/10.1038/nrg3863

11. Hu J., Barlet X., Deslandes L., Hirsch J., Feng D. X., Somssich I., Marco Y. 2008. Transcriptional responses of Arabidopsis thaliana during wilt disease caused by the soil-borne phytopathogenic bacterium, Ralstonia solanacearum. PLoS One, 3 (7): e2589. https://doi.org/10.1371/journal.pone.0002589

12. Jaag H. M., Nagy P. D. 2010. The combined effect of environmental and host factors on the emergence of viral RNA recombinants. PLoS Pathogen, 6: e1001156. https://doi.org/10.1371/journal.ppat.1001156

13. Kandoth P. K., Ranf S., Pancholi S. S., Jayanty S., Walla M. D., Miller W., Howe G. A., Lincoln D. E., Stratmann J. W. 2007. Tomato MAPKs LeMPK1, LeMPK2, and LeMPK3 function in the systemin-mediated defense response against herbivorous insects. Proceedings of the National Academy of Sciences, 104: 12205-12210. https://doi.org/10.1073/pnas.0700344104

14. Kim K. H., Lim S., Kang Y. J., Yoon M. Y. 2016 Optimization of a virus-induced gene silencing system with Soybean yellow common mosaic virus for gene function studies in soybeans. The Plant Pathology Journal, 32 (2): 112-122. https://doi.org/10.5423/PPJ.OA.04.2015.0063

15. Lee W. S., Rudd J. J., Kanyuka K. 2015. Virus induced gene silencing (VIGS) for functional analysis of wheat genes involved in Zymoseptoria tritici susceptibility and resistance. Fungal Genetics and Biology, 79: 84-88. https://doi.org/10.1016/j.fgb.2015.04.006

16. Liscombe D. K., O'Connor S. E. 2011. A virus-induced gene silencing approach to understanding alkaloid metabolism in Catharanthus roseus. Phytochemistry, 72: 1969-1977. https://doi.org/10.1016/j.phytochem.2011.07.001 
17. Li C., Zhang Z., Ghebremariam K., Wang L., Wu L., Liang Y. 2014. A novel method for the evaluation of virusinduced gene silencing efficiency. Genetics and Molecular Research, 13: 9443-9452. https://doi.org/10.4238/2014.November.11.9

18. Liu Y., Schiff M., Dinesh-Kumar S. 2002. Virus-induced gene silencing in tomato. The Plant Journal, 31: 777-786. https://doi.org/10.1046/j.1365-313X.2002.01394.X

19. Mansfield J., Genin S., Magori S., Citovsky V. 2012. Top 10 plant pathogenic bacteria in molecular plant pathology. Molecular Plant Pathology, 13: 614-629. https://doi.org/10.1111/j.1364-3703.2012.00804.x

20. Narusaka M., Kubo Y., Hatakeyama K., Imamura J., Ezura H., Nanasato Y., Tabei Y., Takano Y., Shirasu K., Narusaka Y. 2013. Interfamily transfer of dual NB-LRR genes confers resistance to multiple pathogens. PLoS One, 8 (20): e55954. https://doi.org/10.1371/journal.pone.0055954

21. Padmanabhan M., Savithramma P. D. 2009. Virus-induced gene silencing as a tool for delivery of dsRNA into plants. Cold Spring Harbor Protocols, 2: pdb.prot5139.

https://doi.org/10.1101/pdb.prot5139

22. Patil B. L., Fauquet C. M. 2015. Light intensity and temperature affect systemic spread of silencing signal in transient agro-infiltration studies. Molecular Plant Pathology, 16 (50): 484-494. https://doi.org/10.1111/mpp.12205

23. Ramegowda V., Mysore K. S., Senthil-Kumar M. 2014. Virus-induced gene silencing is a versatile tool for unravelling the functional relevance of multiple abioticstress-responsive genes in crop plants. Frontiers in Plant Science, 5: 323. https://doi.org/10.3389/fpls.2014.00323

24. Schön M., Töller A., Diezel C., Roth C., Westphal L., Wiermer M., Somssich I. E. 2013. Analyses of wrky18 wrky 40 plants reveal critical roles of SA/EDS1 signalling and indole-glucosinolate biosynthesis for Golovinomyces orontii resistance and a loss-of resistance towards Pseudomonas syringae pv. tomato AvrRPS4. Molecular Plant-Microbe Interactions, 7: 758-767. https://doi.org/10.1094/MPMI-11-12-0265-R

25. Senthil-Kumar M., Mysore K. S. 2011. Virus-induced gene silencing can persist for more than 2 years and also be transmitted to progeny seedlings in Nicotiana benthamiana and tomato. Plant Biotechnology Journal, 9 (7): 797-806. https://doi.org/10.1111/j.1467-7652.2011.00589.x
26. Sung Y. C., Lin C. P., Chen J. C. 2014. Optimization of virus-induced gene silencing in Catharanthus roseus. Plant Pathology, 5: 1159-1167. https://doi.org/10.1111/ppa.12186

27. Szittya G., Silhavy D., Molnár A., Havelda Z. 2003. Low temperature inhibits RNA silencing-mediated defence by the control of siRNA generation. The EMBO Journal, 22: 633-640. https://doi.org/10.1093/emboj/cdg74

28. Tuttle J. R., Idris A. M., Brown J. K., Haigler C. H., Robertson D. 2008. Geminivirus-mediated gene silencing from Cotton leaf crumple virus is enhanced by low temperature in cotton. Plant Physiology, 148 (1): 41-50. https://doi.org/10.1104/pp.108.123869

29. Unver T., Budak H. 2009. Virus-induced gene silencing, a post transcriptional gene silencing method. International Journal of Plant Genomics, 209: 198680. https://doi.org/10.1155/2009/198680

30. Vaistij F. E., Jones L. 2009. Compromised virus-induced gene silencing in RDR6-deficient plants. Plant Physiology, 149: 1399-1407. https://doi.org/10.1104/pp.108.132688

31. Wang C., Cai X., Wang X., Zheng Z. 2006. Optimization of Tobacco rattle virus-induced gene silencing in Arabidopsis. Functional Plant Biology, 33: 347-355. https://doi.org/10.1071/FP05096

32. Wege S., Scholz A., Gleissberg S., Becker A. 2007. Highly efficient virus-induced gene silencing (VIGS) in California poppy (Eschscholzia californica): an evaluation of VIGS as a strategy to obtain functional data from non-model plants. Annals of Botany, 100: 641-649. https://doi.org/10.1093/aob/mcm118

33. Wicker E., Lefeuvre P., De Cambiaire J. C., Lemaire C., Poussier S., Prior P. 2012. Contrasting recombination patterns and demographic histories of the plant pathogen Ralstonia solanacearum inferred from MLSA. The ISME Journal, 6 (5): 961-974. https://doi.org/10.1038/ismej.2011.160

34. Zhang C., Bradshaw J., Whitham S., Hill J. 2010. The development of an efficient multipurpose bean pod mottle virus viral vector set for foreign gene expression and RNA silencing. Plant Physiology, 153: 52-65. https://doi.org/10.1104/pp.109.151639

ISSN 1392-3196 / e-ISSN 2335-8947

Zemdirbyste-Agriculture, vol. 105, No. 4 (2018), p. 357-362

DOI 10.13080/z-a.2018.105.045

\title{
Viruso sukelto genų nutildymo panaudojimas eds 1 geno funkcinei analizei Ralstonia solanacearum užkrèstuose pomidoruose
}

\author{
H. R. Bolok Yazdi ${ }^{1}$, S. K. Sabbagh ${ }^{2}$, M. Mazaheri ${ }^{3}$, M. Salari ${ }^{1}$, S. M. Moshtaghioun ${ }^{2}$ \\ ${ }^{1}$ Zabolo universitetas, Iranas \\ ${ }^{2}$ Jazdo universiteto Mokslo miestelis, Iranas \\ ${ }^{3}$ Shahid Sadoughi medicinos mokslų universitetas, Iranas
}

\section{Santrauka}

Viruso sukelto genų nutildymo efektyvumą galima ịvertinti nustatant pasirinkto geno nutildymo laipsnị augaluose. Tyrimo metu valgomojo pomidoro (Lycopersicon esculentum L.) augaluose jautrumo ligoms genas eds 1 buvo nutildytas taikant viruso sukeltą genų nutildymą, naudojant tabako garbanotosios dryžligés viruso (Tobacco rattle virus) raiškos vektoriu. Pomidorai ivairiais augimo tarpsniais (pilnai atsidarius sėklaskiltei ir aštuntojo lapo) esant skirtingoms temperatūroms $\left(20\right.$ bei $28^{\circ} \mathrm{C}$ ) buvo infekuoti $1,0 \times 10^{6}$ ir 1,5 $\times 10^{8} \mathrm{~mL}^{-1}$ koncentracijos Agrobacterium tumefaciens $\mathrm{C} 58 \mathrm{C} 1$ paderme, turinčia eds $1 \mathrm{cDNR}$ geną. Atvirkštinès transkripcijos ir polimerazès grandininès reakcijos (AT-PGR) metodas buvo panaudotas analizuojant eds 1 geno slopinimą ir tiriant viruso sukelto genu nutildymo efektyvumą. tyrimo duomenu analizè parodè didelį eds1 geno nutildymą visiškai atsidariusios sèklaskiltės tarpsniu esant $20^{\circ} \mathrm{C}$ temperatūrai ir panaudojus $1,0 \times 10^{6} \mathrm{KFV}$ koncentracijos $A$. tumefaciens padermę, lyginant su kitomis sąlygomis. Be to, esant ịvairioms sąlygoms nuvytusių augalų procentas smarkiai skyrėsi, o daugiausia ju buvo esant $1,0 \times 10^{6} \mathrm{~mL}^{-1}$ bakterijos koncentracijai ir $20^{\circ} \mathrm{C}$ temperatūrai.

Remiantis tyrimo rezultatais galima teigti, kad eds 1 geno nutildymą galima naudoti kaip galimą žymeklį, siekiant atrinkti bakteriniam vytuliui atsparias rūšis.

Reikšminiai žodžiai: Agrobacterium tumefaciens, agroinfiltracija, eds1, Ralstonia solanacearum, viruso sukeltas geno nutildymas. 